\title{
Biological control of the coffee berry borer Hypothenemus hampei (Coleoptera: Curculionidae) by Phymastichus coffea (Hymenoptera: Eulophidae) in Colombia
}

\author{
J. Jaramillo, ${ }^{1,2}$, A.E. Bustillo ${ }^{2}$, E.C. Montoya ${ }^{2}$ \\ and $\mathrm{C}$. Borgemeister ${ }^{1,3 *}$ \\ ${ }^{1}$ Institute of Plant Diseases and Plant Protection, University of Hanover, \\ Herrenhäuser Str. 2, 30419 Hanover, Germany: ${ }^{2}$ Centro Nacional \\ de Investigaciones de Café, AA 2427, Manizales, Colombia: \\ ${ }^{3}$ International Centre of Insect Physiology and Ecology, \\ PO Box 30772-00100, Nairobi, Kenya
}

\begin{abstract}
The potential of the eulophid parasitoid Phymastichus coffea LaSalle to control coffee berry borer Hypothenemus hampei (Ferrari) populations under field conditions in Colombia was evaluated. Parasitoid adults were released one, five and nine days after artificial infestations of 90-, 150- and 210-day-old coffee berries with $H$. hampei females. The position of the beetle inside the berry and the parasitism levels were assessed ten days after each $P$. coffea release. Parasitism of H. hampei by P. coffea was significantly affected by the age of the berries at the time of infestation, and by the position of the beetle inside the berries. Highest levels of parasitism were recorded in 150-day-old berries (75-85\%) and in 90-day-old berries $(75 \%)$ when $P$. coffea were released one day after the artificial infestation with $H$. hampei. In 150-day-old berries, highest levels of parasitism were recorded for $H$. hampei found in the outer layer of the endosperm followed by beetles penetrating the exocarp. Increasing the time of $P$. coffea releases after the artificial infestations with $H$. hampei led to decreased levels of parasitism in beetles attacking 90- and 150-day-old coffee berries. Low levels of parasitism were recorded in $H$. hampei females infesting older coffee berries because most of the beetles had already constructed galleries deep in the endosperm of the berries, i.e. out of reach of the parasitoid. The potential of $P$. coffea for biological control of coffee berry borer in Colombia is discussed.
\end{abstract}

Keywords: coffee berry borer, Hypothenemus hampei, parasitoids, Phymastichus coffea, coffee, biological control, Colombia

\section{Introduction}

The coffee berry borer Hypothenemus hampei (Ferrari) (Coleoptera: Curculionidae) is the most important coffee

*Author for correspondence

Fax: + 254208561690

E-mail: dg@icipe.org pest worldwide (Le Pelley, 1968; Damon, 2000). It was accidentally introduced to South America in 1913 from its native region in central Africa (Bergamin, 1943), and has since become the main threat to coffee production in several countries including Brazil, Guatemala, Honduras, Ecuador, El Salvador and Bolivia (Bustillo, 2002). In Colombia, $H$. hampei was first recorded in the southern part of the country in August 1988 (Bustillo et al., 1998). To date, it is widespread throughout all coffee-growing regions of Colombia and is 
considered to be the country's number one pest, causing serious economic losses and affecting the economy of more than half a million families in Colombia (Bustillo et al., 1998). Under low pest pressure the conversion factor between freshly harvested coffee berries and parchment coffee is $5: 1$; however, a serious infestation can alter this ratio up to $>17: 1$ (Baker et al., 2002).

Females of $H$. hampei bore galleries into the endosperm of the coffee berries causing two types of damage, premature fall of berries younger than 80 days (Decazy, 1990) and qualitative and quantitative losses in coffee through feeding of the larvae inside the berries (Damon, 2000). Usually a berry is attacked by only one female, the latter often referred to as founder or colonizing female. After the start of oviposition the female wing muscles degenerate, preventing her from colonizing other berries (Ticheler, 1963). The population dynamics of and the infestation pattern by $H$. hampei are closely related to the physiology of the coffee plants. The dry matter content of the endosperm, which increases with age of the fruits, is the most crucial factor determining the attack by $H$. hampei (Salazar et al., 1993). Coffee berries with seeds $<20 \%$ dry matter content are either abandoned after an initial attack, or the female waits in a tunnel bored into the exocarp until the endosperm has accumulated a sufficient amount of dry matter content for the development of her offspring (Alonzo, 1984; Ruiz, 1995).

Initially, Colombian coffee growers tried to combat $H$. hampei infestations predominantly through use of broadspectrum insecticides. However, growing environmental concerns and increasing problems with insecticide resistance (Gongora et al., 2001) stimulated the search for more environmentally friendly control strategies against the coffee berry borer in Colombia. As an exotic outbreak pest in South America, a classical biological control approach was pursued. Initially, two larval-pupal ectoparasitoids of $H$. hampei, the bethylids Cephalonomia stephanoderis Betrem and Prorops nasuta Waterston, which were found in Ivory Coast (Ticheler, 1963) and Uganda (Hempel, 1934), respectively, were introduced to Colombia in the late 1980s (Baker, 1999). They were first tested under laboratory conditions and subsequently released in the field (Benavides et al., 1994; Portilla \& Bustillo, 1995). Although both parasitoids successfully established in Colombia, their impact on field populations of $H$. hampei has been rather limited (Quintero et al., 1998).

In 1996 a third parasitoid of H. hampei, the eulophid Phymastichus coffea LaSalle, was introduced to Colombia. Phymastichus coffea was found in Togo in 1987 (Borbón, 1989) and described by LaSalle (1990). It is a gregarious endoparasitoid of H. hampei females (Borbón, 1989), and usually one male and one female $P$. coffea develop inside each host (Lopez \& Moore, 1998). After being parasitized, the mobility of the H. hampei female is impaired and parasitized females stop oviposition and usually die after 12 days (Feldhege, 1992; Infante et al., 1994). At $23^{\circ} \mathrm{C}$ the life cycle of $P$. coffea is 43 days and the lifespans of males and females are 1-2 and 3-4 days, respectively (Lopez et al., 1997). Since 1996, $P$. coffea has been mass reared at the Centro Nacional de Investigaciones de Café (CENICAFE), in Chinchiná, Colombia, and basic biological studies of the parasitoid have been conducted (Vergara et al., 2001). In 1997 P. coffea was released for the first time in Colombia and its establishment was reported in 1998 (Baker, 1999). Further releases followed and, according to Aristizabal et al. (2004),
P. coffea has established to date on 41 farms in Colombia. The present study reports for the first time the impact of $P$. coffea on field populations of $H$. hampei following releases in a coffee plantation in Colombia.

\section{Materials and methods}

Study site and experimental plot

Experiments were carried out between January and October 2001 on the experimental coffee plantation 'Naranjal-Cenicafé' (latitude $04^{\circ} 59^{\prime} \mathrm{N}$; longitude $75^{\circ} 39^{\prime} \mathrm{W}$; altitude $1400 \mathrm{~m} ; 21.4^{\circ} \mathrm{C}$ mean annual temperature; $2700 \mathrm{~mm}$ precipitation/year; $80 \%$ mean relative humidity) near Chinchiná, Colombia. A five-year-old Coffea arabica (L.) cv. Colombia plantation with 650 trees $(1 \times 1 \mathrm{~m}$ planting distance) was chosen for the experiment. An experimental plot was defined as nine trees arranged in a $3 \times 3$ square, and a total of 72 experimental plots were established. The central tree was labelled and served as the sampling unit. The coffee crop had not previously been treated with synthetic insecticides nor had parasitoids of $H$. hampei been previously released there. However, ' $\mathrm{Re}-\mathrm{Re}^{\prime}$ the cultural control practice against coffee berry borer recommended by CENICAFE (Bustillo et al., 1998), which consists mainly of a rigorous removal of infested coffee berries, was routinely performed in the crop, mimicking normal coffee growing conditions in Colombia. Climatic data including temperature, relative humidity, solar radiation and precipitation, were measured daily during the course of the study.

\section{Insects}

Females of $H$. hampei used in this study were obtained from the CENICAFE stock colony in Chinchiná, where they are mass reared using re-hydrated premium quality parchment $C$. arabica cv. Colombia with $45 \%$ moisture content, under controlled conditions, $24 \pm 1^{\circ} \mathrm{C}, 80 \%$ relative humidity (RH) and complete darkness (Bustillo et al., 1998). On the day the coffee plants were artificially infested, $H$. hampei of mixed age were collected in the rearing unit, transferred to plastic boxes filled with staple paper, and then brought to the field.

Adults of $P$. coffea used in the experiments also originated from the CENICAFE rearing unit. They are mass-produced on $H$. hampei-infested parchment beans, following the protocol developed by Orozco (2002). In the present study, immediately after emergence from the $H$. hampei mummies, the female parasitoids were introduced into plastic vials, and covered with tulle impregnated with a honey-water solution. The vials were then placed in a cool box and transported to the field. Only adults of no more than one hour after emergence were used in the experiment.

\section{Artificial infestations with $\mathrm{H}$. hampei and $\mathrm{P}$. coffea releases}

The experiment was initiated in the last week of February 2001, during the main blossoming of the coffee crop for the subsequent main harvest in October (Salazar et al., 1994). On every branch of the selected trees (sampling units) all berries and already open flowers were removed and only new flowers kept, assuring a subsequent uniformity of the berries during the experiment. One branch in the middle of each tree that had at least 50 healthy flowers was labelled. Coffee trees were infested at 90, 150 and 210 days after blossoming, 
Table 1. ANOVA results for parasitism of coffee berry borer (CBB) Hypothenemus hampei adults by Phymastichus coffea released one, five and nine days after infestation with H. hampei adults on 90-, 150- and 210-day-old coffee berries.

\begin{tabular}{lrrr}
\hline Source of variation & df & F & \multicolumn{1}{c}{$P$} \\
\hline Age of berries & 2 & 28.76 & $<0.0001$ \\
Position of CBB & 3 & 316.51 & $<0.0001$ \\
Age $\times$ position & 6 & 54.62 & $<0.0001$ \\
Time of $P$. coffea release & 2 & 0.97 & 0.3796 \\
Age $\times$ release & 4 & 1.39 & 0.2395 \\
Release $\times$ position & 6 & 7.70 & $<0.0001$ \\
Age $\times$ release $\times$ position & 12 & 12.98 & $<0.0001$ \\
Error & 252 & - & - \\
\hline
\end{tabular}

mimicking the infestation pattern of coffee berry borer in berries of different ages (Salazar et al., 1993). During these periods the mean dry matter content of coffee berries are 22.4, 268.9 and $514.9 \mathrm{mg}$ in 90-, 150- and 210-day-old berries, respectively (Salazar et al., 1994). The selected branches were then covered with an entomological sleeve, and artificially infested with 250 females of $H$. hampei per branch, following the methodology described by Villalba et al. (1995). After $24 \mathrm{~h}$ the sleeves were removed, assuring a $100 \%$ infestation of the berries. The parasitoids were released around the selected branch in a ratio of $1: 1$ to the number of $H$. hampei infested berries per branch, i.e. 50 P. coffea per tree. For each age of infestation, parasitoids were released at three different intervals, i.e. one, five and nine days after the artificial infestation of the branches with $H$. hampei. Consequently, nine treatments based on the combinations of the age of the berries and the time of the $P$. coffea releases after the initial infestation with $H$. hampei were evaluated using eight trees per treatment. Parasitism was assessed ten days after each release of $P$. coffea. For this, all berries of the selected branches were collected and taken to the laboratory where the berries were dissected and then the position of the beetle inside the berry was recorded. The positions of the H. hampei female in the coffee berry were defined as: position A, when the beetle is starting the colonization of a new berry and the penetration of the exocarp begins; position $B$, when the beetle has started penetrating the berry but has not yet reached the endosperm; position $C$, when the beetle has started to bore into the endosperm but has not yet commenced oviposition; and position $\mathrm{D}$, when the beetle has produced a gallery in the endosperm, and one or more of its immature stages are found inside the gallery (Bustillo et al., 1998). Once the position of the beetle was recorded, it was removed from the berry and dissected to detect the immature stages of $P$. coffea inside the abdomen of H. hampei.

\section{Statistical analysis}

For each combination of the age of the berries and the release times of $P$. coffea, i.e. treatments, the rate of parasitism for a given position of the beetle inside the coffee berries was calculated as the ratio between the numbers of parasitized and total $H$. hampei found at this particular position. To precisely assess the interaction effects of the position of the beetle inside the berries (a categorical variable) with the other continuous variables (the time of $P$. coffea releases and the age of the berries at the time of infestation, with $H$. hampei), parasitism levels were evaluated using three- or two-way analysis of variance (ANOVA) using the PROC
GLM procedure of SAS (SAS, 1996). In case ANOVAs yielded significant $F$-values $(P<0.05)$, treatment means were compared using Tukey's test (HSD). Before analysis, parasitism rates were arcsine-transformed, however non-transformed data are presented in the results section.

\section{Results}

Levels of parasitism of $H$. hampei by $P$. coffea were significantly affected by the age of the berries at the time of infestation, the position of the beetle inside the berries, and the age by position interaction (table 1). The time of the $P$. coffea releases after artificial infestation of berries with $H$. hampei did not affect parasitism levels. Similarly, the interaction between time of parasitoid release and age of the berries at the time of infestation had no effect on rates of parasitism. However, the interaction of time of parasitoid release and position of the beetle in the berries, as well as the three-way interaction between berry age at the time of infestation with $H$. hampei, parasitoid release time and the position of the beetle in the berry significantly affected rates of parasitism of $H$. hampei by P. coffea (table 1). Consequently, parasitism levels were compared at a given position of the beetle inside the berries and at a given time of the $P$. coffea releases across the different ages of the coffee berries at the time of infestation with $H$. hampei, as well as at a given age of the coffee berries at the time of infestation, for a given position of the beetle in the berries across the different times of $P$. coffea releases (table 2). In 90-day-old berries, the proportion of $H$. hampei parasitized in position A was significantly higher after one day compared to five and nine days after a $P$. coffea release. Independent of the time of the $P$. coffea releases, hardly any parasitism was detected in adults of $H$. hampei found in position A of 150-and 210-dayold berries. In 90-day-old berries, the level of parasitism in position B $(60 \%)$ was significantly higher when the parasitoids were released one day compared to five and nine days after the artificial infestation with $H$. hampei (table 2). For the same position, significantly lower levels of parasitism were recorded in 150- and 210-day-old berries one day, and in 210-day-old berries also nine days after the parasitoid releases compared to 90 -day-old berries. Significantly fewer $H$. hampei in position B (1.8\%) were parasitized in 210-dayold berries nine days after the $P$. coffea releases compared to the two earlier parasitoid releases (table 2). For H. hampei in position C, highest levels of parasitism were recorded in 150compared to 90- and 210-day-old berries independent of the $P$. coffea release dates (table 2). With increasing time between 
Table 2. Parasitism of coffee berry borer (CBB) Hypothenemus hampei adults ( $\% \pm$ SE) by Phymastichus coffea released one, five and nine days after host infestation in each position of penetration in 90-, 150- and 210-day old coffee berries.

\begin{tabular}{|c|c|c|c|c|}
\hline \multirow{2}{*}{$\begin{array}{l}\text { Position of CBB in } \\
\text { the berries* }\end{array}$} & \multirow{2}{*}{$\begin{array}{c}\text { Time of } P \text {. coffea } \\
\text { release (days) }\end{array}$} & \multicolumn{3}{|c|}{$\mathrm{CBB}$ found parasitized in each position $(\% \pm \mathrm{SE})$} \\
\hline & & 90 days & 150 days & 210 days \\
\hline \multirow[t]{3}{*}{ A } & 1 & $12.5 \pm 3.6 \mathrm{aA}$ & $0.0 \pm 0.0 \mathrm{bA}$ & $0.0 \pm 0.0 \mathrm{bA}$ \\
\hline & 5 & $0.0+0.0 \mathrm{aB}$ & $0.3+0.3 \mathrm{aA}$ & $0.0+0.0 \mathrm{aA}$ \\
\hline & 9 & $0.0 \pm 0.0 \mathrm{aB}$ & $0.5 \pm 0.3 \mathrm{aA}$ & $0.0 \pm 0.0 \mathrm{aA}$ \\
\hline \multirow[t]{3}{*}{ B } & 1 & $60.0 \pm 6.8 \mathrm{aA}$ & $14.5 \pm 3.7 \mathrm{bA}$ & $9.5 \pm 3.7 \mathrm{bA}$ \\
\hline & 5 & $19.0+2.4 \mathrm{aB}$ & $14.3+1.9 \mathrm{aA}$ & $10.8+4.7 \mathrm{aA}$ \\
\hline & 9 & $20.3 \pm 3.3 \mathrm{aB}$ & $25.5 \pm 6.9 \mathrm{aA}$ & $1.8 \pm 0.8 \mathrm{bB}$ \\
\hline \multirow[t]{3}{*}{$\mathrm{C}$} & 1 & $3.3 \pm 1.2 \mathrm{cB}$ & $70.5 \pm 2.9 \mathrm{aA}$ & $19.0 \pm 4.6 \mathrm{bA}$ \\
\hline & 5 & $34.0 \pm 4.6 \mathrm{bA}$ & $66.5 \pm 2.9 \mathrm{aA}$ & $16.5 \pm 4.1 \mathrm{cA}$ \\
\hline & 9 & $29.5+2.5 b A$ & $47.3+6.5 \mathrm{aB}$ & $20.8+2.8 \mathrm{bA}$ \\
\hline \multirow[t]{3}{*}{$\mathrm{D}$} & 1 & $0.0 \pm 0.0 \mathrm{bA}$ & $0.0 \pm 0.0 \mathrm{bB}$ & $3.3 \pm 1.0 \mathrm{aA}$ \\
\hline & 5 & $0.0 \pm 0.0 \mathrm{bA}$ & $0.0 \pm 0.0 \mathrm{bB}$ & $4.5+1.7 \mathrm{aA}$ \\
\hline & 9 & $0.0+0.0 \mathrm{bA}$ & $1.8+0.9 \mathrm{bB}$ & $8.3+1.7 \mathrm{aA}$ \\
\hline
\end{tabular}

Means followed by the same small letter in each row and by the same capital letter in each column are not significantly different $(P>0.05$, Tukey test).

${ }^{*}$ See text for definition of positions A, B, C and D.

artificial infestations with $H$. hampei and $P$. coffea releases, parasitism significantly decreased in 90- and 150-day-old berries. No or only very low parasitism levels were recorded in $H$. hampei found in position D (table 2).

Because of the significant three-way interaction between age $\times$ release $\times$ position (table 1 ) total levels of parasitism could not be compared statistically among age classes of coffee berries and/or parasitoid release time intervals. However, highest levels of total parasitism were recorded in 150day-old berries, and one day after a $P$. coffea release also in 90-day-old coffee berries (table 3). Additionally, percentages of parasitism for a given age of the berries at the time of infestation with $H$. hampei and for a given $P$. coffea release were compared across the different positions of the beetle inside the coffee berries. In 90-day-old berries, significantly highest parasitism levels were recorded in position B one day after the $P$. coffea release and in position $C$ five and nine days after the parasitoid releases (table 3). In 150-day-old berries, independent of the time of the $P$. coffea releases, significantly highest levels of parasitism were found in position C followed by position B. Similarly, in 210-day-old berries, significantly highest parasitism level was always recorded in $H$. hampei found in position C (table 3). For $H$. hampei in position D, low levels of parasitism were only recorded in 150-day-old berries nine days after the $P$. coffea release and in 210-day-old coffee berries independent of the time of the release of the parasitoids (table 3 ).

\section{Discussion}

Levels of parasitism of $H$. hampei approached $85 \%$ following parasitoid releases, suggesting that $P$. coffea had a strong impact on its host under field conditions in Colombia. However, parasitism levels were significantly affected by the developmental stage of the coffee berries and by the position of the beetle inside the coffee berries at the time of the parasitoid releases. The speed of penetration of $H$. hampei in coffee berries depends on the physiological state of the berry, i.e. their dry matter content (Arcila et al., 1993). The time between initial colonization of a coffee berry by a $H$. hampei female, i.e. positions $\mathrm{A}$ and $\mathrm{B}$, and subsequent oviposition, i.e. position D, under field conditions in Colombia are 70 and 5 days, for 90 - and 210-day-old berries, respectively (Ruiz, 1995). In the present study, the highest levels of parasitism were recorded in beetles found in position $C$ of 150-day-old berries independent of the time of the parasitoid releases. At this time, parasitized adult $H$. hampei found in position $\mathrm{C}$ had just begun damaging the

Table 3. Parasitism of coffee berry borer (CBB) Hypothenemus hampei adults ( $\% \pm$ SE) by Phymastichus coffea released after one, five and nine days of infestation in each position of penetration (A, B, C, D) in 90-, 150- and 210-day-old coffee berries.

\begin{tabular}{|c|c|c|c|c|c|c|}
\hline \multirow{2}{*}{$\begin{array}{l}\text { Age of berries at } \\
\text { infestation (days) }\end{array}$} & \multirow{2}{*}{$\begin{array}{l}\text { Time of } P \text {. coffea } \\
\text { release (days) }\end{array}$} & \multirow{2}{*}{$\begin{array}{l}\text { Total parasitism } \\
\qquad(\% \pm S E)\end{array}$} & \multicolumn{4}{|c|}{ CBB found parasitized in each position* $(\% \pm S E)$} \\
\hline & & & A & B & $\mathrm{C}$ & $\mathrm{D}$ \\
\hline \multirow[t]{3}{*}{90} & 1 & $75.5 \pm 6.8$ & $12.5 \pm 3.6 b$ & $60.0 \pm 6.8 \mathrm{a}$ & $3.3 \pm 1.2 \mathrm{bc}$ & $0.0 \pm 0.0 \mathrm{~d}$ \\
\hline & 5 & $53.0 \pm 3.8$ & $0.0 \pm 0.0 \mathrm{c}$ & $19.0 \pm 2.4 b$ & $34.0 \pm 4.6 \mathrm{a}$ & $0.0 \pm 0.0 \mathrm{c}$ \\
\hline & 9 & $49.8 \pm 2.4$ & $0.0 \pm 0.0 \mathrm{c}$ & $20.3 \pm 3.3 b$ & $29.5 \pm 2.5 a$ & $0.0 \pm 0.0 \mathrm{c}$ \\
\hline \multirow[t]{3}{*}{150} & 1 & $85.0 \pm 2.1$ & $0.0 \pm 0.0 \mathrm{c}$ & $14.5 \pm 3.7 \mathrm{~b}$ & $70.5 \pm 2.9 a$ & $0.0 \pm 0.0 \mathrm{c}$ \\
\hline & 5 & $81.0 \pm 2.1$ & $0.3 \pm 0.3 c$ & $14.3 \pm 1.9 b$ & $66.5 \pm 2.9 a$ & $0.0 \pm 0.0 \mathrm{c}$ \\
\hline & 9 & $75.0 \pm 1.4$ & $0.5 \pm 0.3 c$ & $25.5 \pm 6.9 b$ & $47.3 \pm 6.5 a$ & $1.8 \pm 0.9 c$ \\
\hline \multirow[t]{3}{*}{210} & 1 & $31.8 \pm 5.2$ & $0.0 \pm 0.0 \mathrm{c}$ & $9.5 \pm 3.7 \mathrm{ab}$ & $19.0 \pm 4.6 a$ & $3.3 \pm 1.0 b c$ \\
\hline & 5 & $31.8 \pm 4.8$ & $0.0 \pm 0.0 \mathrm{c}$ & $10.8 \pm 4.7 \mathrm{ab}$ & $16.5 \pm 4.1 \mathrm{a}$ & $4.5 \pm 1.7 \mathrm{bc}$ \\
\hline & 9 & $30.8 \pm 3.1$ & $0.0 \pm 0.0 \mathrm{c}$ & $1.8 \pm 0.8 c$ & $20.8 \pm 2.8 a$ & $8.3 \pm 1.7 b$ \\
\hline
\end{tabular}

Means followed by the same letter within each row are not significantly different $(P>0.05$, Tukey test).

* See text for definition of positions A, B, C and D. 
endosperm and in no case were oviposition chambers observed. Female $H$. hampei stop ovipositing and their mobility is impaired after parasitization by $P$. coffea (Feldhege, 1992; Infante et al., 1994). In 90-day-old berries when $P$. coffea was released one day after the artificial infestation with $H$. hampei, around $60 \%$ of the parasitized beetles were found in position B. Yet when the parasitoids were released five or nine days after infestation, highest levels of parasitism were recorded in H. hampei females in position $C$, suggesting that beetles originally attacked by $P$. coffea in position B thereafter penetrated further into the coffee berries. A similar behaviour has been observed in Ips typographus Linnaeus (Coleoptera: Scolytidae) and Tomicobia seitneri (Ruschka) (Hymenoptera: Pteromalidae), where parasitized beetles continued to bore into the bark (Sachtleben, 1952). Likewise, Feldhege (1992) observed that $H$. hampei parasitized by $P$. coffea continued boring into the berries for some days until they died. In laboratory studies, $P$. coffea females were unable to penetrate into coffee berries and attack $H$. hampei females in positions C or D (Borbón, 1989; Infante et al., 1994; Lopez \& Moore, 1998). Thus the high levels of parasitism recorded in 90- and 150-day-old berries might be due to the long time H. hampei were exposed to $P$. coffea while penetrating the exocarp. Once the berries start to mature and have acquired $>20 \%$ dry matter content in the endosperm, $H$. hampei females bore deeper into the berries (Bergamin, 1943; Alonzo, 1984), and are there probably less at risk of an attack by $P$. coffea. This is supported by the low levels of parasitism in H. hampei in 210day-old berries. Then parasitized beetles were predominantly found in position $\mathrm{C}$, though parasitism never exceeded $21 \%$. Moreover, less than $9 \%$ of the beetles found in position $\mathrm{D}$ were parasitized and only in berries older than 159 days. While constructing the galleries in the endosperm, female $H$. hampei often expose their abdomen for short periods outside the berry to remove the detritus (Bustillo et al., 1998), and are then exposed to an attack by P. coffea. This might be one factor explaining the parasitism of $H$. hampei in position D in 210-day-old coffee berries.

The results of the present study showed that $P$. coffea is a promising biological control candidate for coffee berry borer although its parasitism potential decreased with the age of the coffee berries. Consequently, the decision of the release period of $P$. coffea in a coffee plantation should be based on the age of the berries which can be determined by recording the major blossoming period (Bustillo et al., 1998), and also on long-term climatic data. Populations of H. hampei tend to remain inside coffee berries and reproduce at a higher rate during the drier periods, whereas reproduction decreases and migration and subsequent colonization of new berries increase during the rainy season (Baker et al., 1994; Bustillo, 2002). Generally, $H$. hampei populations start colonizing coffee berries between 100 to 150 days after blossoming (Salazar et al., 1993). Since H. hampei females are at this time mainly found in positions A and B, inoculative or augmentative releases of $P$. coffea should be carried out during this period. However, in older berries, > 160 days after blossoming, most of the beetles have already penetrated too deep into the endosperm for P. coffea. Thus other biocontrol agents like the two larval-pupal cryptoparasitoids C. stephanoderis and $P$. nasuta should be released to complement $P$. coffea. Both larval-pupal parasitoids are capable of parasitizing H. hampei in positions C and D (Baker, 1999). However, in field studies so far only low levels of parasitism by these two bethylids have been recorded in Mexico and Colombia (Baker, 1999; Damon, 2000).

The parasitoid-host ratio used in releases in this study was high and could be too costly to implement in an areawide management programme. However, attempts are underway to improve the rearing of $H$. hampei, a crucial factor for the parasitoid production, through the development of an artificial diet (Portilla, 1999). Moreover, the first field releases of $P$. coffea were followed by the successful establishment of the parasitoid in Colombia (Baker, 1999; Aristizabal et al., 2004) suggesting that this parasitoid can be used in classical biological control of the coffee berry borer. In summary, our data clearly underlines the great potential of $P$. coffea for biological control of the coffee berry borer in Colombia and other coffee growing countries of South and Central America.

\section{Acknowledgments}

The authors are very grateful to the director of CENICAFE, Dr Gabriel Cadena Gomez, for his support to this study. Thanks to all staff members of the entomology department at CENICAFE for their technical support. Special thanks to Alvaro Jaramillo Robledo, Mamoudou Sétamou and Lemma Ebssa for helpful comments on earlier versions of this manuscript. This research was partly funded by the DFID-CENICAFE-CABI Bioscience IPM for coffee project (CNTR 93/1536A).

\section{References}

Alonzo, P.F. (1984) El problema de la broca (Hypothenemus hampei (Ferr).) (Col: Scolytidae) y la caficultura. Aspectos relacionados con importancia. Daño, identificación, biología, ecología y control. 242 pp. IICA, PROMECAFE, Guatemala.

Arcila, J., Jaramillo, A., Baldion, V. \& Bustillo, A.E. (1993) La floración del cafeto y su relación con el control de la broca. Avance Técnico No 193. CENICAFÉ, Chinchiná, Colombia.

Aristizabal, L.F., Salazar, H.M., Mejia, C.G. \& Bustillo, A.E. (2004) Introducción y evaluación de Phymastichus coffea (Hymenoptera: Eulophidae) en fincas de pequeños caficultores a través de investigación participativa. Revista Colombiana de Entomología 30, 219-224.

Baker, P.S. (1999) The coffee berry borer in Colombia; final report of the DFID-CENICAFE-CABI Bioscience IPM for coffee project (CNTR 93/1536A). 154 pp. CENICAFÉ, Chinchiná, Colombia.

Baker, P.S., Rivas, A., Balbuena, R., Ley, C. \& Barrera, J.F. (1994) Abiotic mortality factors of the coffee berry borer (Hypothenemus hampei; Coleoptera, Scolytidae). Entomologia Experimentalis et Applicata 71, 201-209.

Baker, P.S., Jackson, J.A.F. \& Murphy, S.T. (2002) Natural enemies, natural allies. Project completion report of the integrated management of coffee berry borer project, $\mathrm{CFC} /$ ICO/02 (1998-2002). 130 pp. CENICAFÉ, Chinchiná, Colombia.

Benavides, M.P., Bustillo, A.E. \& Montoya, E.C. (1994) Avances sobre el uso del parasitoide Cephalonomia stephanoderis para el control de la broca del café Hypothenemus hampei. Revista Colombiana de Entomología 20, 247-253. 
Bergamin, J. (1943) Contribuicao ao conhecimento da biología da broca do café Hypothenemus hampei (Ferrari 1867) (Col.: Ipidae). Arquivos do Instituto Biológico 14, 31-72.

Borbón, M.O. (1989) Bio-écologie d'un ravageur des baies de caféier Hypothenemus hampei Ferr. (Coleoptera: Scolytidae) et de ses parasitoides au Togo. PhD thesis, University of Toulouse, France.

Bustillo, A.E. (2002) El manejo de cafetales y su relación con el control de la broca del café en Colombia. Boletín Técnico No. 24. 40 pp. CENICAFÉ, Chinchiná, Colombia.

Bustillo, A.E., Cardenas, R., Villalba, D., Benavides, P., Orozco, J. \& Posada, F.J. (1998) Manejo integrado de la broca del café Hypothenemus hampei (Ferrari) en Colombia. 134 pp. CENICAFÉ, Chinchiná, Colombia.

Damon, A. (2000) A review of the biology and control of the coffee berry borer Hypothenemus hampei (Coleoptera: Scolytidae). Bulletin of Entomological Research 90, 453-465.

Decazy, B. (1990) Descripción, biología, ecología y control de la broca del cafeto Hypothenemus hampei (Ferrari). pp. 133-139 in Conferencias conmemorativas 50 años de Cenicafé 1938-1988. CENICAFÉ, Chinchiná, Colombia.

Feldhege, M.R. (1992) Rearing techniques and aspects of biology of Phymastichus coffea (Hymenoptera: Eulophidae) a recently described endoparasitoid of the coffee berry borer Hypothenemus hampei (Ferrari) (Coleoptera: Scolytidae). Café Cacao Thé 36, 45-54.

Gongora, C.E., Posada, F.J. \& Bustillo, A.E. (2001) Detección molecular de un gen de resistencia al insecticida endosulfan en una población de broca Hypothenemus hampei (Ferrari) (Coleoptera: Scolytidae) en Colombia, pp. 47-48 in 28th Congreso de la Sociedad Colombiana de Entomología. 8-10 August 2001, Pereira, Colombia.

Hempel, A.A. (1934) Prorops nasuta Waterston no Brasil. Arquivos do Instituto Biologico 5, 197-212.

Infante, F., Murphy, S.T., Barrera, J.F., Gómez, J.W. \& Damon, A. (1994) Cría de Phymastichus coffea parasitoide de la broca del café y algunas notas sobre su historia de vida. Southwestern Entomologist 19, 313-315.

LaSalle, J. (1990) A new genus and species of Tetrastichinae (Hymenoptera: Eulophidae) parasitic on the coffee berry borer, Hypothenemus hampei (Ferrari) (Coleoptera: Scolytidae). Bulletin of Entomological Research 80, 1-7.

Le Pelley, R.H. (1968) Pests of coffee. London, Longmans Green and Co.

Lopez, V.C. \& Moore, D. (1998) Developing methods for testing host specificity of Phymastichus coffea LaSalle (Hymenoptera: Tetrastichinae) a potential biological control agent of Hypothenemus hampei (Ferrari) (Coleoptera: Scolytidae) in Colombia. Biocontrol Science and Technology 8, 397-411.

Lopez, V.C., Baker, P., Cock, J.W. \& Orozco, J. (1997) Dossier on Phymastichus coffea (Hymenoptera: Eulophidae
Tetrastichinae) a potential biological control agent for Hypothenemus hampei (Ferrari) (Coleoptera: Scolytidae) in Colombia. 23 pp. CENICAFÉ, Chinchiná, Colombia.

Orozco, H.J. (2002) Guía para la producción del parasitoide Phymastichus coffea para el control de la broca del café. 19 pp. CENICAFÉ, Chinchiná, Colombia.

Portilla, M. (1999) Mass rearing techniques for Cephalonomia stephanoderis (Hymenoptera: Bethylidae) on Hypothenemus hampei (Coleoptera: Scolytidae) developed using Cenibroca artificial diet. Revista Colombiana de Entomología 25, 57-66.

Portilla, M. \& Bustillo, A.E. (1995) Nuevas investigaciones en la cría masiva de Hypothenemus hampei y de sus parasitoides Cephalonomia stephanoderis y Prorops nasuta. Revista Colombiana de Entomología 21, 25-33.

Quintero, C., Bustillo, A.E., Benavides, M.P. \& Chaves, C.B. (1998) Evidencias del establecimiento de Cephalonomia stephanoderis y Prorops nasuta (Hymenoptera: Bethylidae) en cafetales del departamento de Nariño, Colombia. Revista Colombiana de Entomología 24, 141-147.

Ruiz, C.R. (1995) Efecto de la fenología del fruto de café sobre los parámetros de la tabla de vida de la broca del café Hypothenemus hampei (Ferrari). Ingeniero Agrónomo thesis, Universidad de Caldas, Manizales, Colombia.

Sachtleben, H. (1952) Die parasitischen Hymenopteren des Fichtenborkenkäfers Ips typographus L. Beiträge zur Entomologie 2, 137-189.

Salazar, M.R., Arcila, J., Riaño, N. \& Bustillo, A.E. (1993) Crecimiento y desarrollo del fruto de café y su relación con la broca. Avance Técnico No. 194. CENICAFÉ, Chinchiná, Colombia.

Salazar, M.R., Chaves, B., Riaño, N., Arcila, J. \& Jaramillo, R.A. (1994) Crecimiento y desarrollo del fruto del café Coffea arabica L. var. Colombia. Revista Cenicafé 45, 41-50.

SAS Institute (1996) SAS/Stat user's guide. SAS Institute, Cary, North Carolina.

Ticheler, J. (1963) Estudio analítico de la epidemiología del escolítido de los granos de café, Stephanoderis hampei Ferr. en Costa de Marfil. Revista Cenicafé 14, 223-294.

Vergara, J.D., Orozco, H.J., Bustillo, A.E. \& Chaves, B. (2001) Dispersión de Phymastichus coffea en un lote de café infestado de Hypothenemus hampei. Revista Cenicafé 52, 104-110.

Villalba, G.D., Bustillo, A.E. \& Chaves, B. (1995) Evaluación de insecticidas químicos para el control de la broca del café en Colombia. Revista Cenicafé 46, 152-163.

(Accepted 16 May 2005)

(C) CAB International, 2005 